\title{
Imaging spectroscopies to characterize a 13th century Japanese handscroll, The Miraculous Interventions of Jizō Bosatsu
}

\author{
Matthew L. Clarke ${ }^{1 *} \mathbb{D}$, Francesca Gabrieli1 ${ }^{1,2,3}$, Kathryn L. Rowberg ${ }^{4}$, Andrew Hare ${ }^{1}$, Jiro Ueda ${ }^{1}$, \\ Blythe McCarthy ${ }^{1}$ and John K. Delaney ${ }^{2^{*}}$
}

\begin{abstract}
Scientific imaging of a large fragile work of art can be especially challenging, but especially rewarding to better grasp the complexity and changes that have occurred during its creation and lifetime. Here, noninvasive imaging, macro X-ray fluorescence (MAXRF) imaging spectroscopy and reflectance imaging spectroscopy, from the visible to the near infrared spectral range, are utilized to document a 14-m-long Japanese narrative handscroll, The Miraculous Interventions of Jizō Bosatsu. Due to the scroll's age and its handling during past use as a teaching tool, it has a number of conservation needs and shows evidence of past repairs. The scroll has extensive and severe creasing, breaks and tears, as well as unstable and powdering pigments. Microscopic observation and scientific analyses were performed both to document the current condition of the scroll and to better understand its long history. Combining RIS and MAXRF allowed for pigment characterization through elemental and molecular information. While RIS and MAXRF previously have been applied to the study of other painted materials, their application to East Asian paintings is rare. The obstacles of the scroll's length and fragile uneven surface were overcome by optimizing the setups of the two imaging systems. The MAXRF and RIS analyses, here focused on a select scene of the scroll, found certain original pigments common in early Japanese scroll paintings were used frequently, such as vermilion, iron-based compounds (yellow and red ochres), and copper-containing greens, while others occurred sparingly, such as azurite and red lead. A chloride-containing lead-based white pigment was employed. Faded organic colorants, notably indigo as well as an organic yellow/brown, could be detected but their vibrancy has been muted over the centuries. In the case of indigo, it may be visibly observed in some areas; however, analysis revealed its previously unknown presence mixed with a copper green in a select area. This focused study sets a foundation for further studies on both this object and other Asian works of art.
\end{abstract}

Keywords: Japanese, Handscroll, Imaging, XRF, FORS, Conservation, Pigment

\footnotetext{
*Correspondence: clarkem@si.edu; j-delaney@nga.gov

1 Department of Conservation and Scientific Research, Freer Gallery of Art and Arthur M. Sackler Gallery, National Museum of Asian Art, Smithsonian Institution, Washington, DC 20013-7012, USA

${ }^{2}$ Scientific Research Department, National Gallery of Art, Washington, DC 20001, USA

Full list of author information is available at the end of the article
}

\begin{abstract}
Introduction
The Miraculous Interventions of Jizō Bosatsu (Freer Gallery of Art, Smithsonian Institution, Washington, DC: Gift of Charles Lang Freer, F1907.375a) is a Japanese handscroll dating to the mid-thirteenth century which has one of the earliest surviving depictions of this narrative in Japanese art. Artistically, the scroll demonstrates the skill and versatility of an unknown artist in painting people of all social classes with sympathy and realism in a uniquely Japanese style. These richly painted scenes are
\end{abstract}


bridged by explanatory text. The scroll had been heavily used as a teaching tool, and has undergone restoration efforts prior to its purchase by Charles Lang Freer (1854-1919) in 1907 through art dealer Nomura Yozo (1870-1965) of the firm Samurai Shokai based in Yokohama, Japan.

This handscroll has been noted in art historical articles because it illustrates scenes from an early version of the narrative text [1-4]. Despite interest in this early narrative handscroll, there has been little investigation into materials that may allow for better understanding of its production and changes across its approximately $14 \mathrm{~m}$ length and $30 \mathrm{~cm}$ width. There are many conservation issues that have been documented which must be addressed to ensure the scroll's preservation yet complicate the scientific investigation. These include fading, discoloration, losses, cracks, breaks, tears, flaking and unstable pigments. Examples of these conservation concerns are represented in Fig. 1. The mounting is also badly creased and delaminated in many places.

Furthermore, previous treatments and alterations over the lifetime of the painting complicate a full understanding of the original work, yet may also shed light on past restoration and collecting practices. While these efforts are not documented, there are clues to many of the changes that occurred. Over centuries, handscrolls were made in a consistent manner, such as this example, by attaching regularly sized sheets of paper along the left and right edges of the sheets to make a long, continuous surface. Several of the sheets of paper in this handscroll, primarily those containing text, are significantly narrower indicating that they were trimmed. This often was done to remove mistakes from the text, with the addition of rewritten, short sections of paper, during the production process. Shorter sections of paper may also have been used to complete illustrated scenes. Many handscrolls had sections removed over time as samples for collectors of calligraphy and images from old and important artworks. Some of the texts and images in this scroll are incomplete or missing, favoring the latter supposition. This observation is further supported by close examination of the damage to the scroll, especially the countless creases running across its surface that developed over centuries of use. Though some edges of the paper sheets may have been trimmed lightly during reoccurring remountings, inconsistencies in the creases passing through the seams in the papers indicate where sections were more heavily trimmed, removed or are out of sequence. Additionally, Japanese painter Kanō Tan'yū (1602-1674) created a copy of a portion of the scroll in 1627 CE (F1907.375b).

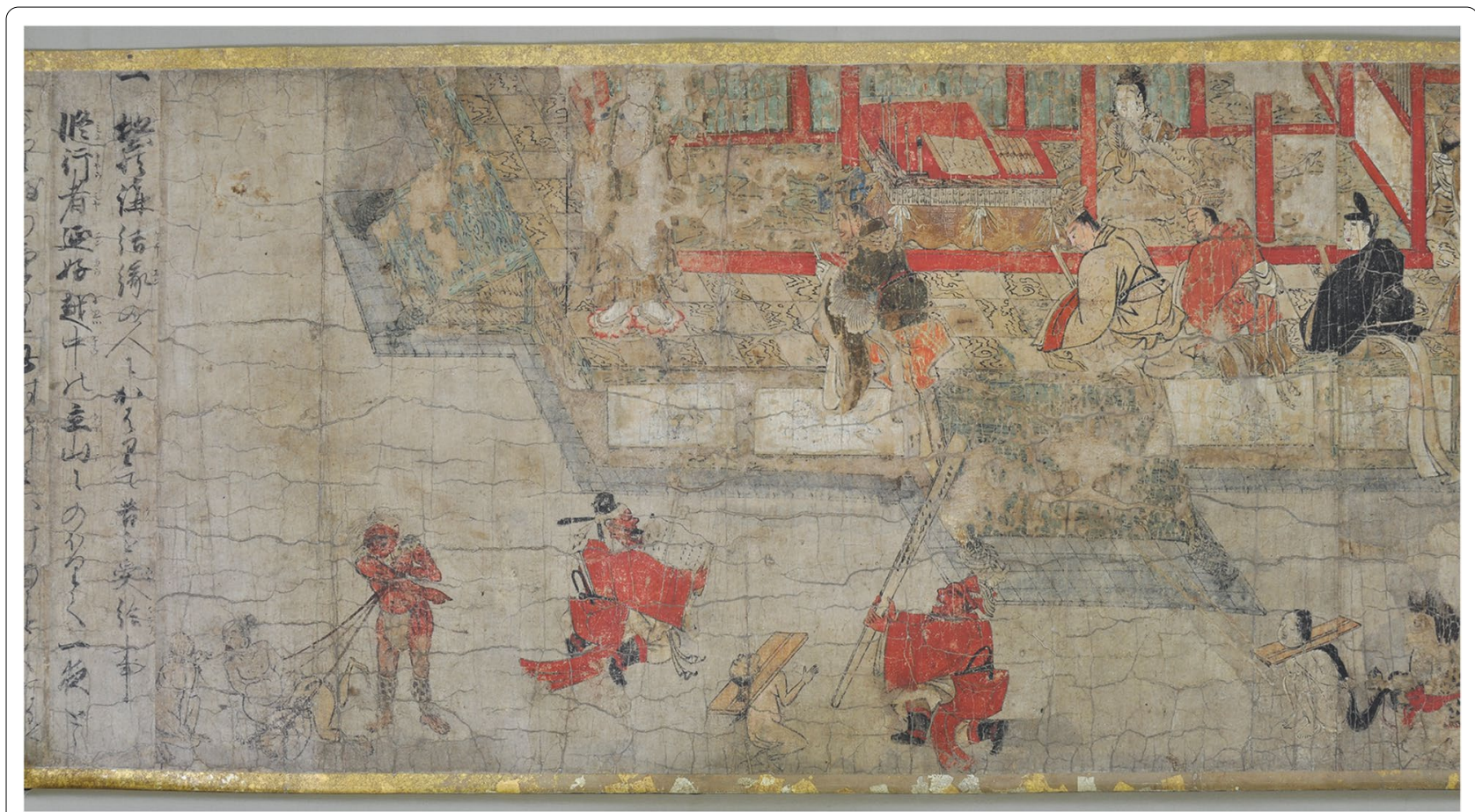

Fig. 1 A section of the handscroll, The Miraculous Interventions of Jizō Bosatsu (Freer Gallery of Art, Smithsonian Institution, Washington, DC: Gift of Charles Lang Freer, F1907.375a), depicting Jizō among the Kings of Hell. Cracks, abrasions, and degraded pigments are observed. The gold border is from non-original mounting material decoration 
Differences between these two works suggest that some text is now missing from the original [2].

As a first step in the study of the materials, non-contact, non-destructive imaging-based techniques were chosen to characterize the pigments of the delicate scroll. Specifically, reflectance imaging spectroscopy (RIS) from the visible to the near infrared (400 to $1000 \mathrm{~nm}$ ), macro $\mathrm{x}$-ray fluorescence imaging spectrometry (MAXRF), were performed sequentially. Such methods are increasingly used in the investigation of painted surfaces. These imaging techniques were supplemented by point-based analyses: fiber-optic reflectance spectroscopy (FORS) from 350 to $2500 \mathrm{~nm}$ (extended spectral range and greater spectral resolution than RIS) and XRF point analyses (at finer spectral and spatial resolutions and longer acquisition times).

Reflectance imaging spectroscopy (RIS), also known as reflectance hyperspectral imaging, consists of the collection of spatial co-registered images in many contiguous spectral bands such that the reflectance spectrum can be constructed for each spatial pixel. While it was developed for the remote sensing field, it has found applications in many other fields including art conservation science [5, 6]. Complementarily to the elemental information gained through the MAXRF imaging technique, RIS provides molecular information and allows for the identification and mapping of chemical compounds present in the artworks. RIS is usually performed from the visible near infrared (NIR) to the short-wave IR range, from 400 to $2500 \mathrm{~nm}$, and has been used for identification and mapping of pigments and paint binders on easel paintings and illuminated manuscripts [7] and also mural paintings [8]. Despite the greater prevalence of these tools, their application to the scientific investigations of East Asian scroll painting is limited. Site specific point XRF and reflectance spectroscopies have been implemented for the analyses of scrolls [9, 10]. Research into other Japanese painted or printed surfaces, such as screens and woodblock prints, has also leveraged point and imagingbased spectroscopies [11-19]. Only recently Asian artworks have been studied through imaging spectroscopy with the aim of characterizing the materials [20]. Li et al. developed a large-scale RIS scanning system to measure a large Chinese scroll and combined the result with MAXRF data [21]. However, even such a system cannot directly accept a long handscroll without user intervention and handling. Additionally, the detailed investigation of scrolls that have been heavily handled (i.e., showing cracks and losses attributed to use) through their lifetime must be further explored, requiring great care in the manner in which they can be imaged, accounting for topography and creases that have formed with use.

Each object investigated by these imaging methodologies brings its own unique challenge. Here, requirements included that the scroll be unrolled to a given scene, positioned, and remaining in a flat horizontal position. The size and fragility of the scroll prevents it from being imaged while in a vertical orientation. This necessitated mounting the RIS camera and the MAXRF scanning system above the artwork, aimed downward (Fig. 2). In each case a conservator unrolled and positioned the scroll beneath each instrument. While the entirety of
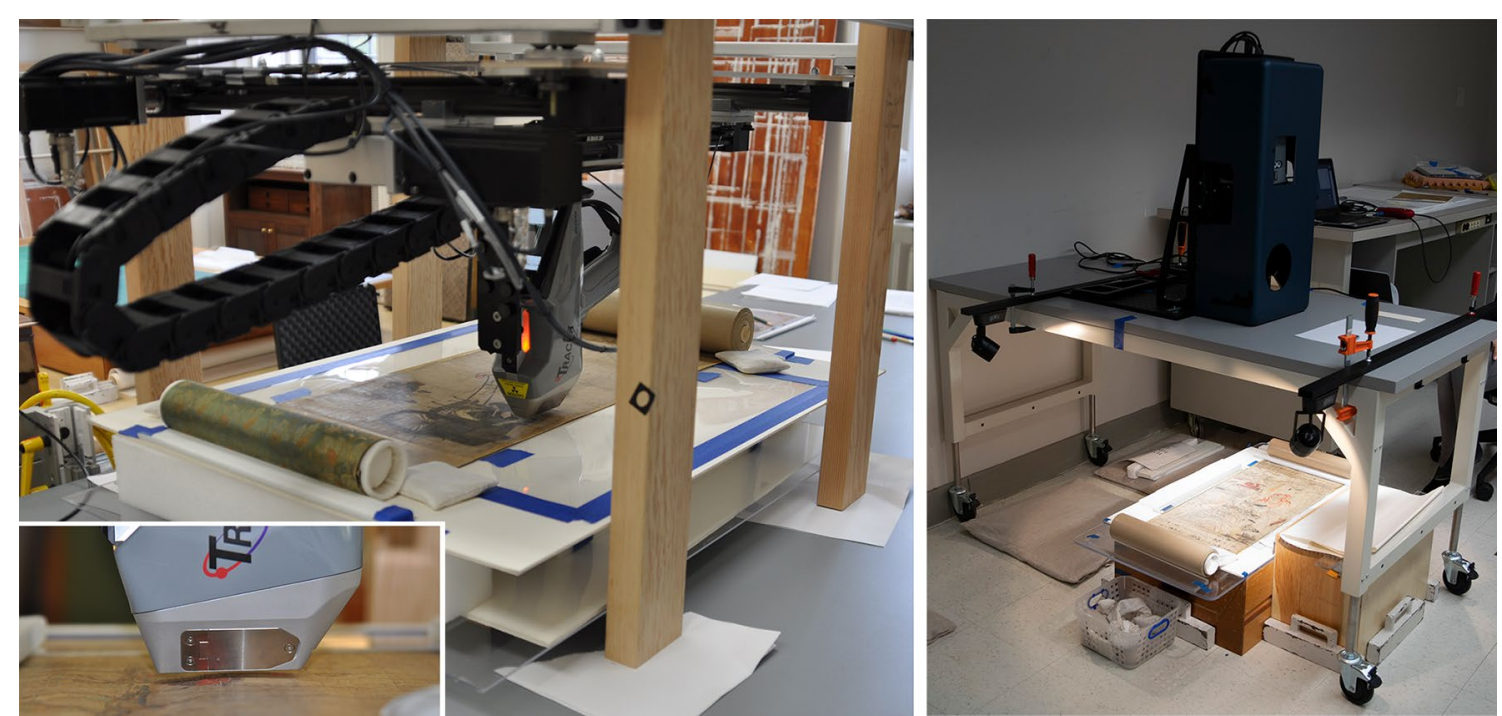

Fig. 2 The (left) MAXRF and (right) reflectance imaging spectroscopy (RIS) setups for imaging of the handscroll. Inset shows the proximity of the XRF system to the surface and highlights the surface topology of the scroll 
the scroll was documented by RIS, only small sections on each sheet were captured by MAXRF due to the close measurement distance of this technique coupled with the scroll topography and time constraints. For the MAXRF scanning the scroll was positioned underneath the MAXRF system and raised to the correct height by inserting paperboard shims. The surface topology then could be minimized, but not eliminated, by gently placing weights at the scroll edges. For the RIS imaging the camera was mounted vertically above a hole in a height adjustable table which allowed imaging of the unrolled portion of the scroll.

Though data collection and analyses were carried out across the handscroll, the research presented in this manuscript will focus on a scene partway through that illustrates Jizō Bosatsu appearing before the Kings of Hell to promote compassion in the judgement of the souls before them (Fig. 1). This scene is chosen based on the range of colors represented as well as some of the characteristics of degradation and damage observed. Here, Jizō appears on the upper left side of the veranda with King Emma, in the brown green robes, at the center. Other kings and attendants are present on the platform and below.

\section{Results and discussion}

Visual and microscopic observation of this section of the scroll reveals the fine painted details present throughout the work. However, it also reveals areas of flaking and degraded paints (Fig. 3). The figure of Jizō on the left side of the veranda shows heavy damage and evidence of subsequent repair.

MAXRF scanning and analysis focused on two central figures of the scene, which differ greatly in their degree of

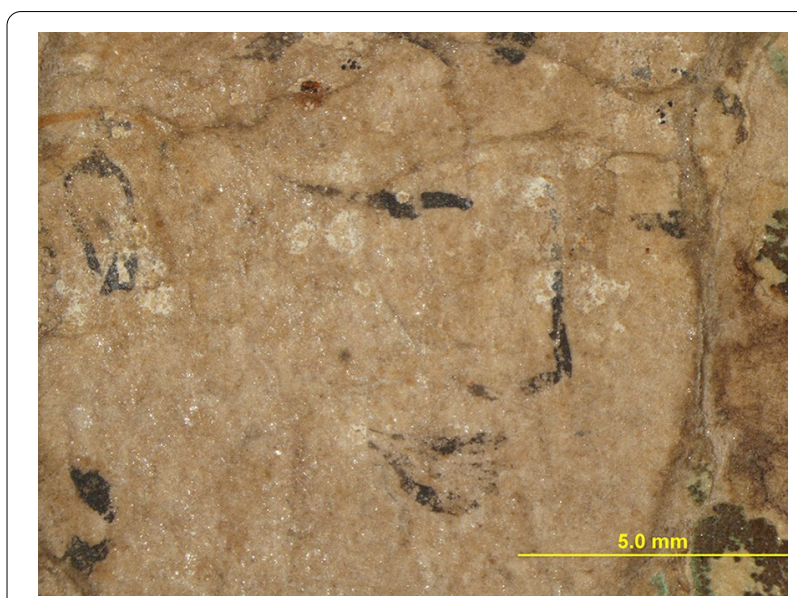

Fig. 3 Photodocumentation image of the face of Jizō, showing the fine drawing detail drawing and the significant loss of white paint preservation. The figure of Jizō shows significant damage, while King Emma remains intact (Fig. 4). In XRF x-ray radiation is used induce emission of fluorescent X-rays from the paint in order determine the chemical elements present from which the pigments used can be inferred. Scanning the MAXRF system over an area allows one to build an image map of the distribution of a given element, with greater amounts of the element appearing brighter in the image map. Elemental maps of the figures of Jizō and King Emma are given in Fig. 4. It should be noted that measured XRF signals will include not only those from the thin paint layer but also those from the underlying clay-loaded paper and supporting materials (also paper based). The presence of mica on the surface of the scroll has also been noted, likely from the transfer of this material from the coating of a previous replacement backing. Calcium $(\mathrm{Ca})$, silicon $(\mathrm{Si})$ and small iron (Fe) XRF signals are present throughout the scroll from the mica and clay.

RIS data was collected from the complete scene and a basis set of reflectance spectra was found using multivariant statistical imaging processing. These basis or endmember spectra were used to make spectral maps (Fig. 5). RIS provides molecular information about the pigments, specifically the electronic transitions which are complementary to the elemental information from MAXRF. The ability of extending the results of the combined technique to the rest of the scene is certainly an advantage of the detailed RIS analysis. Using the reflectance spectral features and the elemental information from the MAXRF the pigments were determined. Due to the very thin paint layers and signals from the supporting material, analysis of the binder material by FORS was not conclusive; it is likely an animal glue, the traditional binder for Japanese paintings of this time [22].

Despite significant loss of paint, several observations can be made with regard to the figure of Jizō. MAXRF maps show that a lead $(\mathrm{Pb})$ white paint was used for the face, hands, chest and feet. The presence of copper $(\mathrm{Cu})$ and microscopic investigation suggests the use of a copper green-pigment to decorate Jizō's robes. Only small marks of green remain, yet this is sufficient for detection by MAXRF. Higher iron $(\mathrm{Fe})$ signals indicate the presence of an iron-containing pigment, visible in the edges of the figure (Fig. 4). No evidence for ochres such as red ochre (containing hematite, $\mathrm{Fe}_{2} \mathrm{O}_{3}$ ) or brownish ochre (containing goethite $\mathrm{FeO}(\mathrm{OH})$ ) or even yellow ochre (containing $\left.\mathrm{FeO}(\mathrm{OH}) \cdot \mathrm{nH}_{2} \mathrm{O}\right)$ have been detected with RIS in this area (lack of characteristic absorptions in the 700 to $950 \mathrm{~nm}$ region of iron oxides and hydroxides [6]), maybe due to degradation phenomena. Also, no red ochre, or hematite, has been detected in Jizō's inner or outer garments. There are, indeed, areas of complete loss in the center of the 

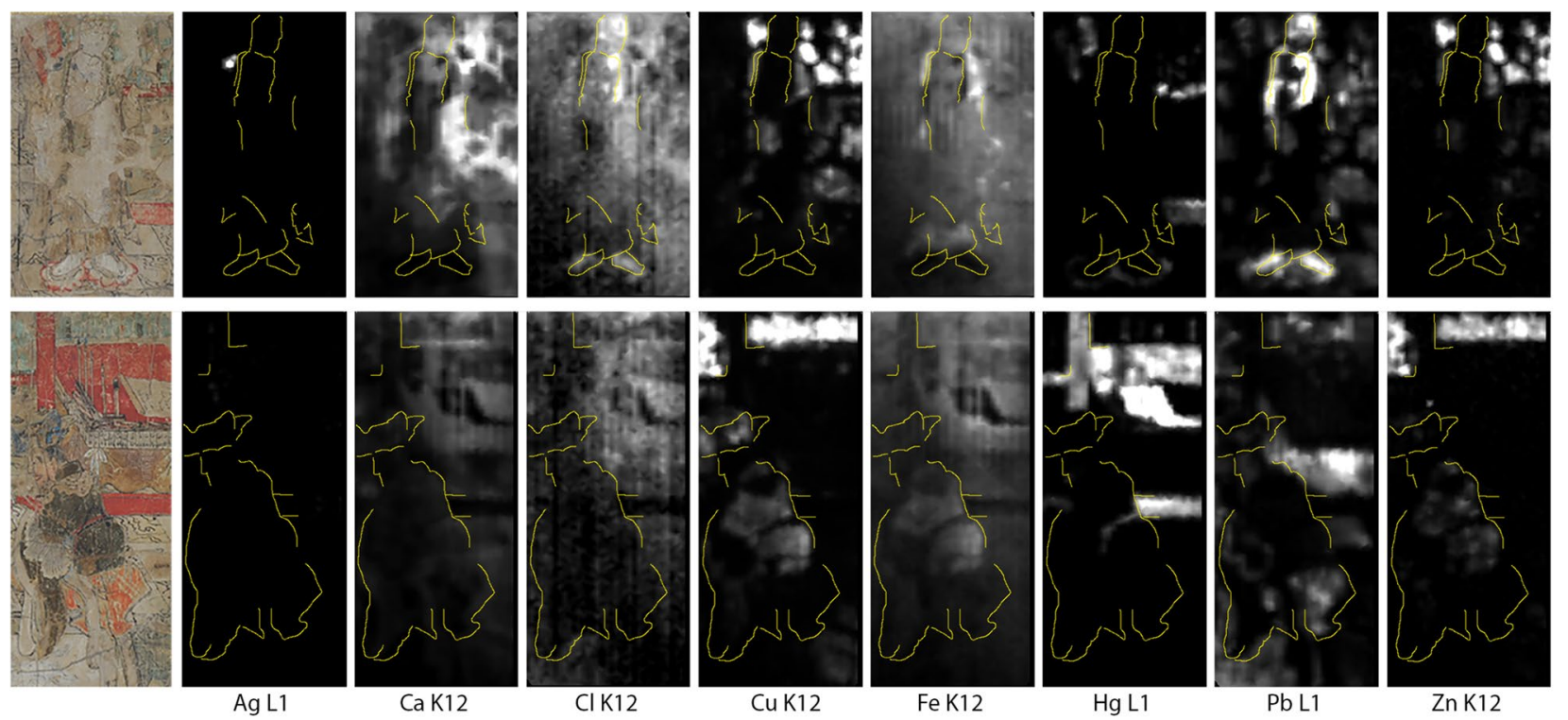

$(0-500)$

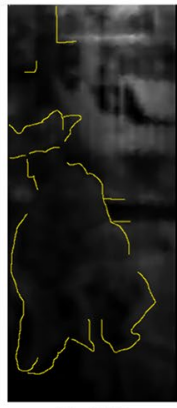

Ca K12

(500-20000)

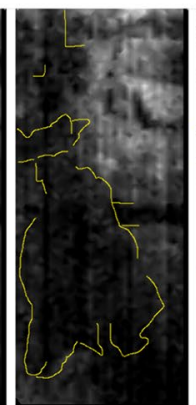

$\mathrm{Cl} \mathrm{K12}$

(20-800)

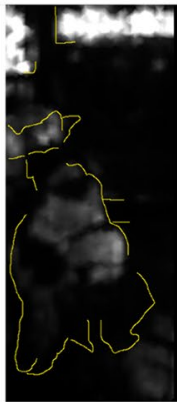

Cu K12

(150-20000)

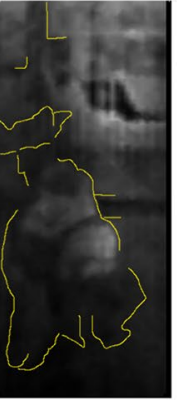

Fe K12 (100-5000)

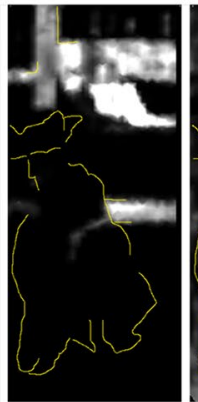

$\mathrm{Hg} \mathrm{L} 1$ (200-12000)

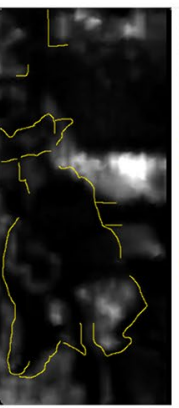

$\mathrm{Pb} \mathrm{L1}$ (300-10000)

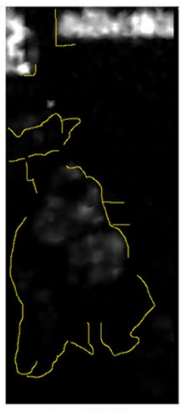

Zn K12 (50-2000)

Fig. 4 Selected MAXRF element maps from two areas of interest (top) Jizō and (bottom) King Emma. MAXRF scan areas are approximately $7 \times 12 \mathrm{~cm}$ and $7 \times 16 \mathrm{~cm}$, respectively. Outlines of the figures are drawn in yellow. Intensity scales for each element line series are shown below. Some intensity variation may be attributed to the surface topology resulting in a greater gap between object and instrument (e.g. see the Ca K12 and Fe K12 maps)

figure, where higher calcium and silicon signals can be observed. In these cases, there is no pigment assignment to be made by RIS or MAXRF as the original pigments and supporting material are completely missing. MAXRF shows the presence of mercury $(\mathrm{Hg})$ underneath Jizo's feet, where through RIS, the presence of vermilion or cinnabar (HgS) is found (Fig. 5). The associated red endmember shows a narrow transition edge around $600 \mathrm{~nm}$ characteristic of the $\mathrm{HgS}$ semiconductor [6]. It should be noted that the aim of this research is not to differentiate between the forms of $\mathrm{HgS}$ : natural form cinnabar and synthetic form vermilion. Here, we will refer to all forms of $\mathrm{HgS}$ as vermilion.

An unexpected XRF silver (Ag) signal at the top left of the figure necessitated further investigation. This signal arises from two small areas of repair near Jizō's shoulder (Fig. 6) of similar tone as darker nearby gray black pigment. It is probable that this was a repair performed with reused materials. Scrolls made from sheets of thick, clayloaded paper, such as this example, are prone to delamination. Until recently, it was common practice to remedy this problem by splitting the paper into two layers. The back layer of the paper was then cut up, flipped over and used to patch losses in the front layer of the support paper because it was a compatible match. Since the back surface of scrolls were often decorated with drawings in silver or gold $(\mathrm{Au})$, these decorations sometimes appear inadvertently in the repairs of losses. Similar silver decoration has been observed in other repaired sections of this scroll. Paper fiber analysis combined with careful observation, mapping and matching of the old repair papers during conservation treatment and remounting could be used to support this hypothesis.

The figure of King Emma shows several pigments seldomly seen in the handscroll: a dark blue and an orange red. MAXRF data supports the initial assumption that these are likely a copper blue (azurite, $\mathrm{C}_{2} \mathrm{H}_{2} \mathrm{Cu}_{3} \mathrm{O}_{8}$ ) and lead red $\left(\mathrm{Pb}_{3} \mathrm{O}_{4}\right)$ (as opposed to vermilion given the presence of lead but lack of mercury), respectively. These assignments were confirmed by RIS and FORS measurements. As visible in Fig. 5, the RIS red lead endmember, shows an inflection point at about $580 \mathrm{~nm}$ which is blue shifted from the vermilion inflection point at $600 \mathrm{~nm}$ more indicative of red lead than vermilion [6]. The RIS blue endmember maps the blue in the hat of the King Emma and has the typical reflectance spectral shape of azurite, such as a maximum of reflectance around $450 \mathrm{~nm}$ and absorbance centered at $700 \mathrm{~nm}$ [23]. The FORS spectra show narrow absorptions at 2284 and $2353 \mathrm{~nm}$ indicative of the hydroxyl and carbonate groups of azurite [23]. These spectral features are different than the green endmember spectra (that present a maximum of reflectance at $530 \mathrm{~nm}$ (green) and absorbance centered at $700 \mathrm{~nm}$ and FORS does not show any evidence 

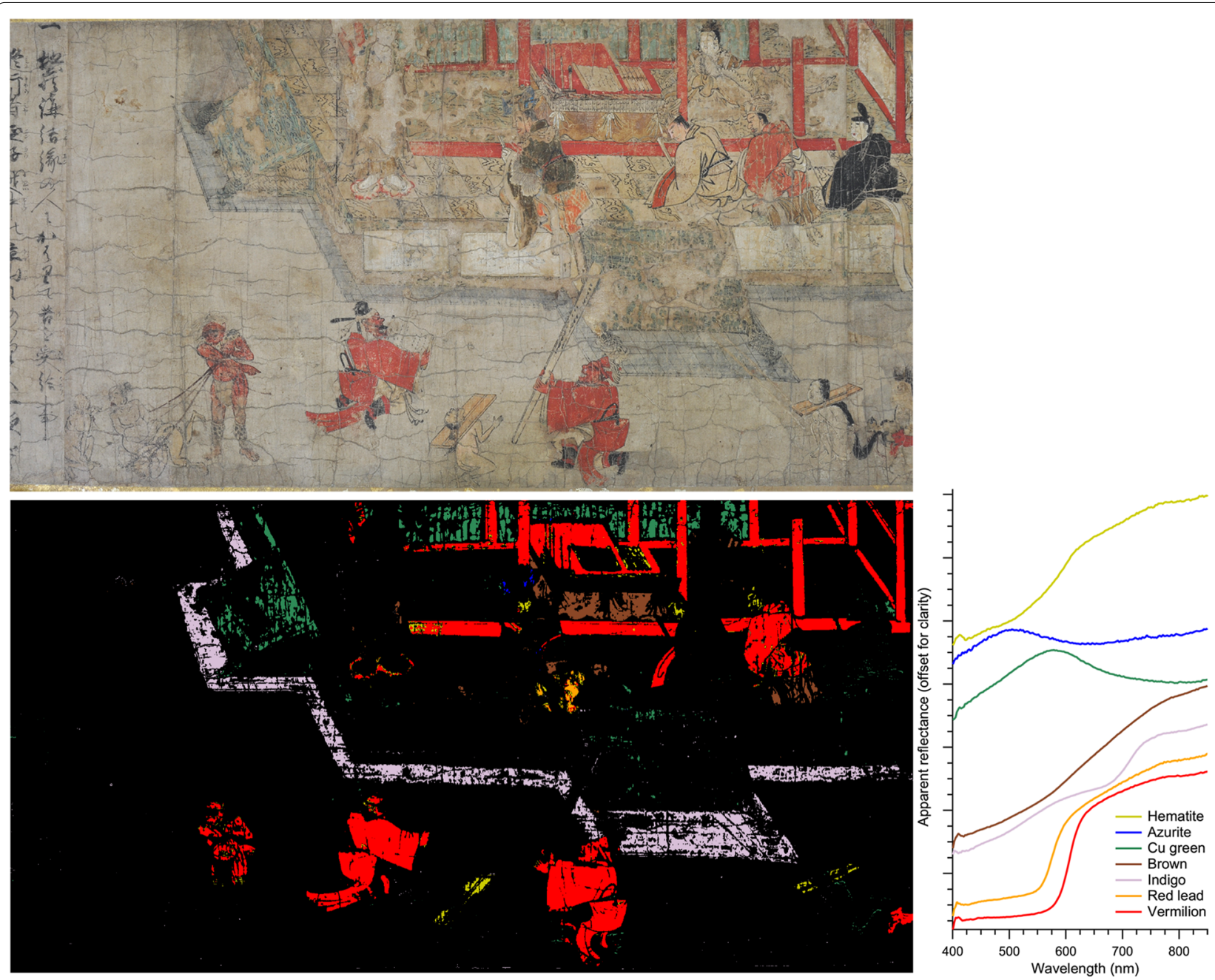

Fig. 5 (Top) The area of the scroll analyzed by reflectance imaging spectroscopy (RIS). (Lower left) The map of the reflectance spectral endmembers obtained from the spectral angle mapping algorithm. (lower right) the reflectance spectral endmembers, zoomed to the $400 \mathrm{~nm}$ to $850 \mathrm{~nm}$ region, found from analysis of the RIS data cube

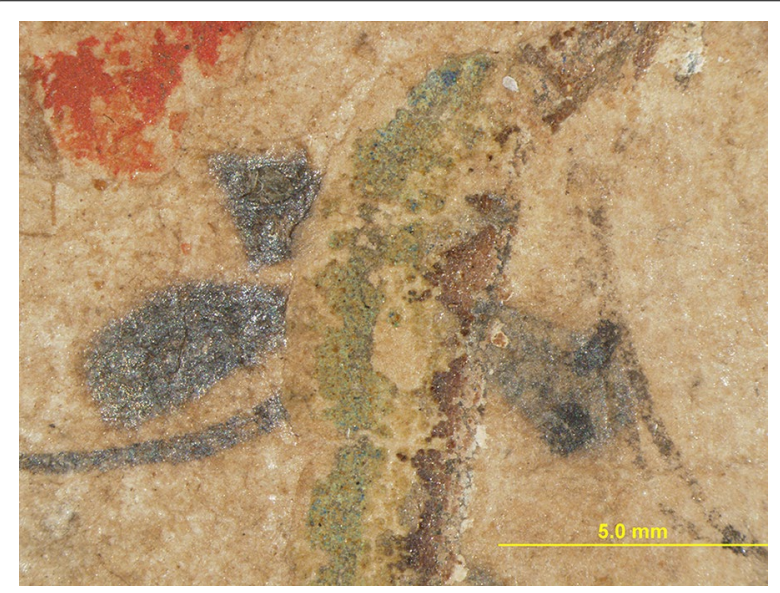

Fig. 6 Photodocumentation image from near Jizo's shoulder, showing two silver paper fills to the left of the copper green line of hydroxyl and carbonate groups spectral features) that maps the visually green areas of the scene. These spectral features are more common with copper-based greens such as malachite $\left(\mathrm{Cu}_{2} \mathrm{CO}_{3}(\mathrm{OH})_{2}\right)$ [23]. A small azurite signal is also observed by RIS in the brushes resting vertically atop of the altar.

There are extended areas that present high copper in the XRF signal. Significant copper green containing areas include the bamboo blinds behind the altar as well as the wooden flooring in this area. Additional copper XRF signals can be observed as outlining portions of Jizō's robes. Far weaker copper signals can be found in the decorative tiles on the veranda floor. Malachite was commonly used as a green pigment in Japan and its color could be altered by the method of processing [22]. FORS analysis rules out the presence of azurite in these green areas for the 
reasons noted above. Chloride-containing copper greens, such as atacamite or paratacamite, are unlikely due to the lack of correlation between the $\mathrm{Cu}$ and $\mathrm{Cl}$ maps (Fig. 4). Comparing the copper and zinc MAXRF maps, there are many similar trends. With the exception of the azurite, the other copper areas all have a detectable level of zinc as well. A scatter plot of copper to zinc intensities shows there are green pigments having different zinc-to-copper ratios (Fig. 7) suggesting there are copper pigments present that vary slightly in their elemental composition. For example, the green bamboo blinds (highlighted green in Fig. 7) and King Emma's blue hat as well as the blue brush tips on the altar (highlighted blue) are readily differentiated based on the zinc-to-copper intensity ratios of approximately $6-8 \%$ and $<1 \%$, respectively. Other regions on the scatterplot are less directly linked to a specific aspect of the painting and may include mixtures that contain a copper green pigment (e.g., King Emma's brown green robe). Zinc is present in minerals containing copper and may be found in the refined pigment [24]. Such zinc content in copper green pigments has been observed in Japanese and Western paintings [25-28], and may be attributed to zinc carbonate minerals, such as rosasite and zincrosasite.
A trace XRF arsenic (As) signal also was observed in the green bamboo blinds; however its source is not determined at this time. Since the As signal is approximately $1 \%$ the intensity of the $\mathrm{Cu}$, it is most likely a trace element in an accessory mineral from the ore. Trace amounts of arsenic within copper pigments have been previously noted and these compounds may similarly be found in copper-containing ores [27-29]. The chemical nature of the zinc and arsenic compounds within this scene cannot be deduced from the data; however its presence may aid investigations into the sources of the different pigments found throughout this scroll as well as serve as useful reference points when comparing to other similar works.

MAXRF and RIS also show the altar and writing table was painted with vermilion with a lead white. The pigment of the brown altar drapery has not been identified and may be from a discolored organic yellow as the XRF spectra do not find any characteristic element. RIS data shows an increase in reflectance with increasing wavelength for the brown endmember which maps to the brown areas such as the brown altar drapery. This is consistent with the behavior of an organic material (Fig. 5, see endmember "brown").

Contrarily, red ochre or hematite has been found, through RIS, in the planks attached around the necks

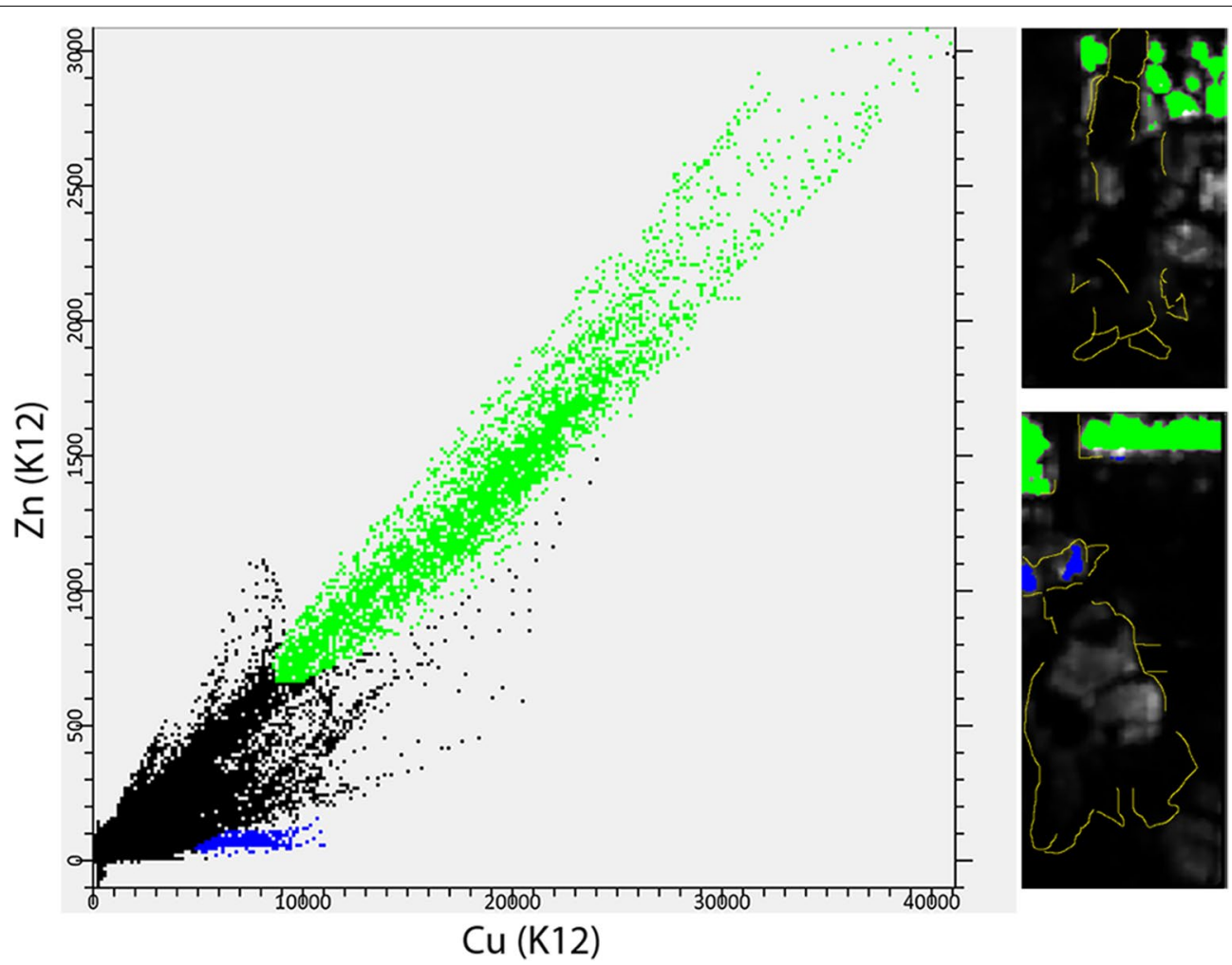

Fig. 7 (Left) Band intensity scatter plot of the zinc and copper XRF K12 line intensities from each point with select regions highlighted in green or blue and (right) the corresponding regions overlaid on the Cu K12 intensity map. Outlines of the figures are drawn in yellow 
of the souls near the bottom of the scroll, supported by point XRF which shows elevated iron levels. It also has been detected in the faces of King Emma and his attendants and in some details in the altar, as is shown in the RIS map results for the yellow endmember (Fig. 5, hematite areas colored yellow). The spectral endmember has the characteristic spectral features of hematite: an increase in reflectance around $580 \mathrm{~nm}$ turning into a maximum at $650 \mathrm{~nm}$, a second maximum around $750 \mathrm{~nm}$ and an absorption at about $840 \mathrm{~nm}$ [6]. Elevated iron levels were not detected in the face of Emma though this maybe due to matrix effects from the presence of lead and mercury.

Thicker areas of vermilion are present on the raised writing desk atop the altar as determined from the combined results of MAXRF and RIS. This area corresponds to very high mercury signals. This area may have had a thicker vermilion paint layer to distinguish the desk from the altar, however later restoration cannot be completely ruled out. It should be noted that the past restoration treatments of this scroll would be expected to use many of the same traditional pigments as for its original production. RIS cannot determine the application date of the vermilion, but further study into the impurities and inflection point shifts may help differentiate vermilion pigments $[23,30]$.

An RIS endmember corresponding to indigo maps the muted slate stones surrounding the platform that may have been a more vibrant color in the past (Fig. 5 . indigo endmember colored pink). Indigo was identified by its inflection point near $720 \mathrm{~nm}$ [23]. It is also notable that indigo was found in the central staircase along with the copper green (Fig. 8), but not in the side staircase. This could not be observed in normal viewing, as both staircases appear as a similar color, though the degradation and discoloration of the paper complicate visual interpretation. It is not immediately known if this was part of the initial composition or part of a later restoration nor whether the indigo gave a subtle change or a more vibrant hue to the green stairs. In either case, it would appear to be a decided choice to accentuate the central staircase by this mixture of colors.

RIS mapping of the white pigmented areas was challenging as the spectra, in the visible range, are similar to the background paper. As noted previously, much of the thin white lead paint has flaked from the surface. However, in some notable areas, such as Jizō's feet and the panels on the side of the veranda a white pigment is present and it was possible to map it using the mixture tuned matched filtering (MTMF) algorithm (Fig. 8). The spectral endmember has no clear spectral features in the 400 to $1000 \mathrm{~nm}$ range that allows for the identification of the pigment used. A previous investigation of a separate section of this scroll identified the lead based white

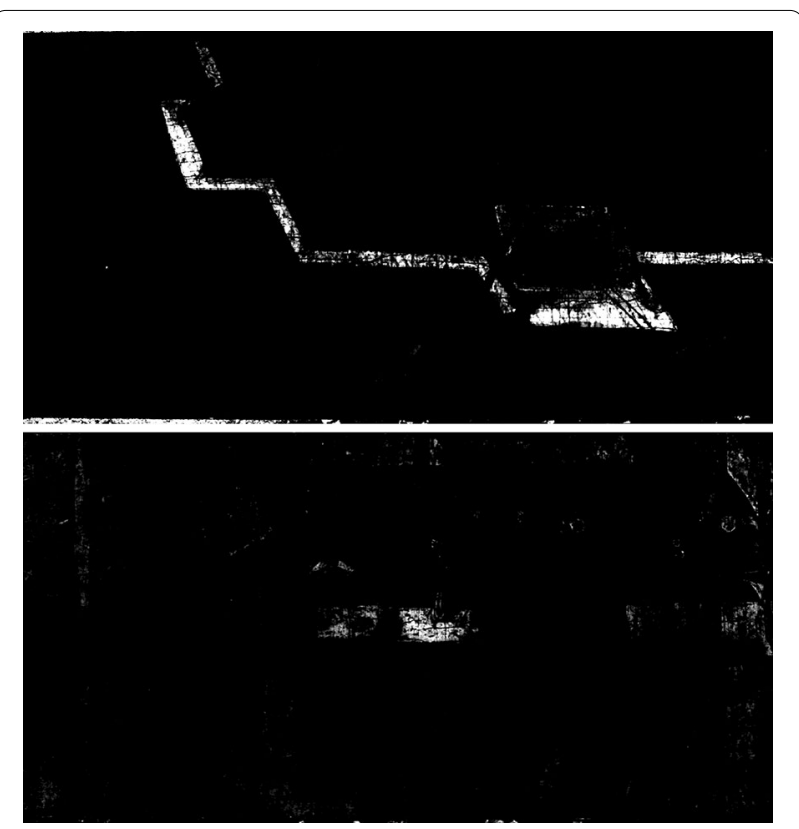

Fig. 8 Reflectance imaging spectroscopy maps showing the distribution of (top) indigo and (bottom) lead-based white obtained with ENVI's MTMF algorithm

via sampling and examination by $\mathrm{XRD}$ as laurionite, $\mathrm{PbCl}(\mathrm{OH})$ [31]. A wide range of white pigments, including several lead-based whites, have been employed in Japanese paintings $[22,31,32]$. Due to the very thin paint, it was not possible to determine any specific features of the lead-based white employed in this scene by FORS. The $\mathrm{Cl}$ map (Fig. 4) shows elevated intensity in areas of high $\mathrm{Pb}$ content. Point XRF analyses on the white ribbon of the altar hanging show the presence of lead and chlorine. The peak intensities of this segment show lead and chlorine intensities that are very similar to reference laurionite as well as to the previously sampled area (and very different from basic lead carbonate); however, additional techniques would be required for confirmation. Other lead white and chlorine containing compounds may be present, such as blixite [31].

\section{Conclusions}

Non-invasive spectral mapping measurements, such as MAXRF and RIS demonstrated here, and are found to be ideal tools for the investigation of fragile painted works of art. Combining these two techniques proved beneficial, particularly when supplemented by point analysis methods. Together these methods were found to greatly increase the confidence of pigment assignments of such thin paint layers. Small amounts of pigment in damaged areas can still be found with these methods. However, when entire sections of the paint and support are lost, 
the information of the pigments originally present cannot be recovered. Yet, clues to restoration methods, such as the reuse of the silver-containing paper, may be found through the scientific analyses and close examination during the remounting of such works. Further, elemental information, such as the presence of zinc and trace levels of arsenic in copper-containing greens may prove fruitful when comparing mineral sources and manufacturing methods.

While this research has particularly centered on a single scene from the handscroll, further information about its creation may be obtained by comparing across the different sections of the scroll. This scene showing the Kings of Hell does account for many of the pigments and is fairly characteristic of the color palette of the earlier section of the scroll. On the whole, this earlier section is more vibrantly colored, while the later sections become more muted. There are some pigments and color choices not captured within the scene under investigation. Of particular note, pink-colored garments were used solely in one scene earlier in the scroll and were found to be a mixture of a lead-based white and vermilion. Similarly, a later scene employs a mask decorated in gold, the only use of the metal aside from the non-original border. Subsequent sections also use more frequent uses of a dark brown ochre and brighter yellows ochres. While all these pigments are known for their use in traditional Japanese paintings [22], additional investigation is warranted into the artistic decisions for pigment choices depending on the depicted illustrations.

\section{Experimental methods}

MAXRF was performed using a Tracer $5 \mathrm{~g}$ (Bruker) handheld XRF with a graphene window and $1.2 \mathrm{~mm}$ collimator connected to an MPS-400E Mobile Art Scanner (Dewitt Systems). The Tracer Rh anode was operated at $45 \mathrm{kV}$ and $40 \mu \mathrm{A}$ with no filter and a $1.2 \mathrm{~mm}$ collimator. Data was collected by rectangular raster scans across the surface of the painting over a mylar support at $2 \mathrm{~mm}$ per second with the Tracer positioned roughly $5 \mathrm{~mm}$ from the scroll surface. Weights were used to reduce the scroll topology, yet some height differences could not be mitigated. XRF elemental data was fitted in Artax software (Bruker), giving the net elemental counts (background signal removed). Fitted elements, related to the instrument and the artwork, included $\mathrm{Ag}, \mathrm{Al}, \mathrm{Ar}, \mathrm{As}, \mathrm{Au}, \mathrm{Ca}$, $\mathrm{Cl}, \mathrm{Cu}, \mathrm{Fe}, \mathrm{Hg}, \mathrm{K}, \mathrm{Mn}, \mathrm{Ni}, \mathrm{P}, \mathrm{Pb}, \mathrm{Rh}, \mathrm{S}, \mathrm{Si}, \mathrm{Sr}, \mathrm{Ti}$ and $\mathrm{Zn}$. The resulting file was exported, reformatted, and plotted in ENVI (L3Harris Geospatial) and Surfer (Golden Software) for interpretation.

RIS was performed with a custom SOC-730 visiblenear infrared camera (Surface Optics) [33]. To accommodate imaging of the long handscroll, the camera was mounted vertically over a hole in a table with the scroll positioned below and used a $f / 5.6$ aperture. Illumination used four SoLux $4700 \mathrm{~K}$ lights. The scroll was unrolled to a given sheet and imaged by 1-3 captures along its length depending on the sheet dimensions. This yielded an image with one pixel being $1 / 3 \mathrm{~mm}$.

Data processing and analysis was performed in ENVI. For more details see Delaney [6]. Images were flat-field corrected by white reference paper (Color-aid) images. Calibration of the RIS data cube to apparent reflectance was performed using $99 \%$ and $2 \% 25 \mathrm{~mm}$ diameter Spectralon reflectance standards (LabSphere). Image registration was performed according to Conover [34]. The identification of the basis set of reflectance spectra or spectral endmembers was done using the ENVI Spectral Hourglass Wizard tool. In brief, the tool allows the user to find spectra clustered in a reduced spectral space obtained by a noise whitening principal component analysis in the spectral dimension of the data cube. The reflectance endmember spatial distribution is then mapped using either spectral angle mapping (SAM) or mixture tuned matched filtering (MTMF) [35] algorithms included in the ENVI software.

FORS measurements over the spectral range of 350 to $2500 \mathrm{~nm}$ were taken using a FieldSpec 3 (Malvern Panalytical) using a $30 \mathrm{~W}$ halogen fiber optic illuminator set at 45 degrees to the surface normal collecting fibers. The spot size at surface of the work of art is $2 \mathrm{~mm}$ diameter and typically 32 spectra were averaged for each reflectance spectrum. Data collection time was $7 \mathrm{~s}$ per point and the light level was about $5000 \mathrm{~lx}$. Point XRF analyses were taken using an Artax spectrometer (Bruker) with a Rh tube with capillary optics operated at $40 \mathrm{kV}$ and $400 \mu \mathrm{A}$ for $60 \mathrm{~s}$ acquisitions in an air environment.

\section{Acknowledgements \\ The authors thank Frank Feltens (Freer and Sackler) and Alessandro Bianchi (former Freer and Sackler) for their discussion of the history and importance of the handscroll. We thank Kathryn Dooley (National Gallery of Art) for discus- sions regarding RIS analysis. Aaron Shugar (Buffalo State) and Bruce Kaiser provided support and advice regarding the MAXRF analyses. Akiko Niwa (Freer and Sackler) provided assistance with the scroll and literature.}

\section{Authors' contributions}

MLC was involved with RIS and MAXRF collection, interpretation and developed the manuscript with FG, who led the RIS imaging and interpretation. KLR acquired the MAXRF data and aided in its interpretation. AH provided guidance on the conservation and historical aspects of the work. JU provided handling and positioning expertise and for scroll and insights into its construction. BM coordinated the scientific research concept. JD advised on the RIS acquisition plan and supported analysis. All authors read and approved the final manuscript.

\section{Funding}

Fellowship funding for Gabrieli and for supplies was provided by the Hirayama Program for Japanese Painting Conservation and the Edward Waldo Forbes Fund of the Freer Gallery of Art. 


\section{Availability of data and materials}

The datasets used and/or analyzed during the current study are available from Dr. Matthew L. Clarke on reasonable request.

\section{Competing interests}

The authors declare that they have no competing interests.

\section{Author details}

${ }^{1}$ Department of Conservation and Scientific Research, Freer Gallery of Art and Arthur M. Sackler Gallery, National Museum of Asian Art, Smithsonian Institution, Washington, DC 20013-7012, USA. ${ }^{2}$ Scientific Research Department, National Gallery of Art, Washington, DC 20001, USA. ${ }^{3}$ Scientific Department, Rijksmuseum, XX 1071 Amsterdam, The Netherlands. ${ }^{4}$ Department of Chemistry \& Physics, Purdue University Northwest, Hammond, IN 46323, USA.

\section{Received: 11 December 2020 Accepted: 5 February 2021}

Published online: 16 February 2021

\section{References}

1. Sachio Y. Freer Gallery of Art Jizō Engi (フリーア画廊の地蔵縁起). J A rt Studies (美術研究). 1938;76:1-16.

2. Umezu J. Freer Gallery of Art Jizō Genkie and the miniature by Tanyu ( フリア画廊の地藏験記絵と探幽縮図). J Yamato Bunka (大和文華館). 1953;13:61-9.

3. Komatsu, S (Ed.). San'nō reigenki; Jizō Bosatsu reigenki (Record of miracles performed at the San'nō Shrine; Record of miracles performed by Jizō Bosatsu). Zoku Nihon emaki taisei (続日本絵巻大成,Survey of Japanese handscroll paintings: Supplement), 12.. Tokyo: Chuokoron-sha (中央公論 社); 1984

4. Yamamoto, S. The subject of the first scene of the Jizō Bosatsu Reigenki in the Freer Gallery of Art Collection: Jealousy and quarreling as sins of women (フリーア美術館所蔵「地蔵菩薩霊験記」第一話の主題 -女 性の罪業としての媛妬と諍い-). Bulletin of the Graduate Division of Letters, Arts and Sciences of Waseda University (早稲田大学大学院文学研 究科紀要). 2020;65:347-359.

5. Fischer C, Kakoulli I. Multispectral and hyperspectral imaging technologies in conservation: current research and potential applications. Stud Conserv. 2006;51(sup1):3-16.

6. Delaney JK, Zeibel JG, Thoury M, Littleton RO, Palmer M, Morales KM, de La Rie ER, Hoenigswald AN. Visible and infrared imaging spectroscopy of Picasso's Harlequin musician: mapping and identification of artist materials in situ. Appl Spectrosc. 2010;64:584-94.

7. Cucci C, Delaney JK, Picollo M. Reflectance hyperspectral imaging for investigation of works of art: old master paintings and illuminated manuscripts. Acc Chem Res. 2016;49:2070-9.

8. Liang $\mathrm{H}$. Advances in multispectral and hyperspectral imaging for archaeology and art conservation. Appl Phys A. 2012;106:309-23.

9. Sugihara K, Tamura K, Satoh M, Hayakawa Y, Hirao Y, Miura S, Yotsutsuji H, Tokugawa Y. Analysis of pigments used in scroll paintings of a national treasure "Tale of Genji" using a portable x-ray fluorescence spectrometer. Adv X-ray Anal. 2001;44:432-41.

10. Hayakawa Y, Shirono S. X-ray fluorescence analysis of illustrated scrolls of the legends of Shigisan, a national treasure. Sci Conserv. 2018;57:91-100.

11. Leona M, Winter J. Fiber optics reflectance spectroscopy: a unique tool for the investigation of Japanese paintings. Stud Conserv. 2001;46:153-62.

12. Yoshida N. Analysis of blue color materials by visible reflection spectra and their second derivative spectra. Sci Conserv. 2011;50:207-15.

13. Quattrini MV, loele M, Sodo A, Priori GF, Radeglia D. A seventeenth century Japanese painting: Scientific identification of materials and techniques. Stud Conserv. 2014;59:328-40.

14. Leona M, Londero PS, Perry J, Fukunage K, Bailey GH, Hale C. Designing nature: Ogata Kōrin's technical choices in Irises at Yatsuhashi. In: Sgamellotti A, Brunetti BG, Miliani C, editors. Science and art: the painted surface. Cambridge: Royal Society of Chemistry; 2014. p. 336-53.

15. Pérez-Arantegui J, Rupérez D, Almazán D, Díez-de-Pinos N. Colours and pigments in late ukiyo-e art works: a preliminary non-invasive study of Japanese woodblock prints to interpret hyperspectral images using in-situ point-by-point diffuse reflectance spectroscopy. Microchem J. 2018;139:94-109.

16. Hayakawa Y, Shirono S. 早川泰弘, 城野誠治. 国宝日月四季山水図の 蛍光 X線分析: 日本絵画における白色顔料の特殊な利用例. 保存科 学 (X-ray fluorescence analysis of "Sun and Moon Landscape of Four Seasons," a national treasure: A special example of the use of white pigment in Japanese painting. Sci Conserv). 2019; 58:83-93.

17. Korenberg CF, Pereira-Pardo L, McElhinney PJ, Dyer J. Developing a systematic approach to determine the sequence of impressions of Japanese woodblock prints: the case of Hokusai's 'Red Fuji.' Herit Sci. 2019. https:// doi.org/10.1186/s40494-019-0250-5.

18. Edwards $G$, Villafana T. Multi-analytic characterization of colorants in two impressions of an Utagawa Toyoharu perspective print. J Cult Herit. 2020;45:48-58

19. Vermeulen M, Burgio L, Vandeperre N, Driscoll E, Viljoen M, Woo J, Leona M. Beyond the connoisseurship approach: creating a chronology in Hokusai prints using non-invasive techniques and multivariate data analysis. Herit Sci. 2020;8:1-13.

20. Biron C, Mounier A, Le Bourdon G, Servant L, Chapoulie R, Daniel F. Revealing the colours of ukiyo-e prints by short wave infrared range hyperspectral imaging (SWIR). Microchem J. 2020;28:104782.

21. Li GH, Chen Y, Sun XJ, Duan PQ, Lei Y, Zhang LF. An automatic hyperspectral scanning system for the technical investigations of Chinese scroll paintings. Microchem J. 2020;155:104699.

22. Winter J. East Asian paintings: materials, structures and deterioration mechanisms. London: Archetype Publications; 2008.

23. Aceto M, Agostino A, Fenoglio G, Idone A, Gulmini M, Picollo M, Ricciardi P, Delaney JK. Characterisation of colourants on illuminated manuscripts by portable fibre optic UV-visible-NIR reflectance spectrophotometry. Anal Methods. 2014;6:1488-500.

24. Siddall R. Mineral pigments in archaeology: their analysis and the range of available materials. Minerals. 2018;8:201. https://doi.org/10.3390/ min8050201.

25. Martin E, Eveno M. Contribution to the study of old green copper pigments in easel paintings. In: International Conference on Nondestructive Testing, Microanalytical Methods and Environment Evaluation for Study and Conservation of Works of Art. 1992. p. 779-792.

26. Yasuhiro H. Portable XRF analysis of Japanese historical objects. Adv X-ray Anal. 2004:47:36-41.

27. Hayakawa Y. Newly-identified copper-based green-colored pigments and the works they were used for. Sci Conserv. 2009;48:109-17. https://doi. org/10.18953/00003745.

28. Gabrieli F, Dooley KA, Facini M, Delaney JK. Near-UV to mid-IR reflectance imaging spectroscopy of paintings on the macroscale. Sci Adv. 2019;5:eaaw7794

29. Berrie $\mathrm{BH}$, Leona $\mathrm{M}, \mathrm{McL}$ aughlin $\mathrm{R}$. Unusual pigments found in a painting by Giotto (c. 1266-1337) reveal diversity of materials used by medieval artists. Herit Sci. 2016. https://doi.org/10.1186/s40494-016-0070-9.

30. Gettens RJ, Feller RL, Chase WT. Vermilion and Cinnabar. In: Roy A, editor. Artists' Pigments: A Handbook of Their History and Characteristics, vol. 2. London: Archetype; 2012. p. 168-9.

31. Winter J. Lead white in Japanese paintings. Stud Conserv. 1981;26:89-101.

32. Naruse M: 成瀬正和. 正倉院宝物の無機顔料調査 (ヘッドライン: 文化財 保存で活躍する化学). 化学と教育. 2007;55:68-71. http://doi.org/https:// doi.org/10.20665/kakyoshi.55.2_68

33. Delaney JK, Dooley KA, Van Loon A, Vandivere A. Mapping the pigment distribution of Vermeer's Girl with a Pearl Earring. Herit Sci. 2020;8:4.

34. Conover DM, Delaney JK, Loew MH. Automatic registration and mosaicking of technical images of old master paintings. Appl Phys A. 2015:119:1567-75.

35. Boardman JW, Kruse FA. Analysis of imaging spectrometer data using $\mathrm{N}$-dimensional geometry and a mixture-tuned matched filtering approach. IEEE Trans Geosci Remote Sens. 2011;49:4138-52.

\section{Publisher's Note}

Springer Nature remains neutral with regard to jurisdictional claims in published maps and institutional affiliations. 